\title{
STATUTES RELATING TO TELEPHONES.
}

(Continued.)

Nebraska, by chap. 10 of the General Laws of 1887 , p. 123 (approved March 30, I887), in designating and regulating cities having a population of sixty thousand inhabitants, or upwards, as cities of the metropolitan class, provides-

SEc. 50. The Mayor and Council shall have power to regulate and provide for the lighting of streets, laying down gas pipes, and erection of lamp posts, electric towers, or other apparatus, and to regulate the sale and use of gas and electric lights, and fix and determine the price of gas, the charge of electric light, and the rent of gas metres within the city, and regulate the inspection thereof, and to regulate telephone service and the use of telephones within the city, and to fix and determine the charges for telephones and telephone service and connections, and to prohibit or regulate the erection of telegraph, telephone, or electric wire poles in the public grounds, streets, or alleys, and the placing of wires thereon, and to. require the removal from the public grounds, streets or alleys of any or all such poles, and require the removal and placing under ground of any or all telegraph, telephone, or electric wires.

By chap. 87, General Laws of I887, p. 634, being "an act, granting the right of way to telegraph or telephone companies along public highways, and providing for a penalty in case of malicious injury or interference with the same" (approved March 30, 1887), it is enacted-

SeCtron 1. That any telegraph or telephone company, incorporated or doing business in this State, shall be and is hereby granted the right of way along any of the public roads of this State for the erection of poles and wires; Provided, That poles shall be set at least six feet within the boundary line of said roadway, and not placed so as to interfere with road crossings; and Provided, That said wires shall be placed at the height of not less than twenty feet above all road crossings.

SF.. 2. Any person or persons who shall break, injure, destroy, or otherwise interfere with the poles, wires or fixtures of any telegraph or telephone company in this State, shall be subject to action and penalty prescribed in section 98 , chapter 13 , Criminal Code.

New Hampshire has "An act to legalize the erection of telegraph and telephone poles and wires, and similar structures for electric lighting," approved 9th August, I88I (chap. 54, Laws, p. 472),- 
SEC. 1. The proprietors of any telegraph line, or of any telephone exchange, or line of telephones used for the transmission of spoken messages, by means of the electric speaking telephone, or of lines for establishing electric lights in this State, may erect and maintain the necessary poles and structures, and stretch the necessary wires for the use of such telegraph line or telephone exchange, or line of telephones, or line for electric lighting, over, across, and along any public highway in this State, or may lay the same under the surface of any such highway.

SEc. 2. Such telegraph, telephone, or electric lighting poles, structures and wires shall be erected and maintained subject to the provisions of chapter 80 of the General Laws of this State relating to telegraphs, which are hereby made applicable to lines of wire for telephonic and electric lighting purposes; and no poles, structures or wires are hereby authorized that shall in any way impede or obstruct the free and safe use of any highway for public travel, nor that shall interfere with or obstruct the safe, free, and convenient use of, or access to or from, any lands or buildings adjoining or near such highway; and no such poles or other structures shall be erected, or wires stretched, by any of șuch proprietors, on, over, or across the lands or buildings of any individuals, or corporations, without their consent; and no right shall be acquired by the nse of wires stretched on, over, or across the lands or buildings of any such individual or corporation, for any length of time.

SEc. 3. Whenever any such proprietors shall desire to erect their poles or structures, or to stretch their wires, they may apply by petition to the Mayor and aldermen of any city, or the selectmen of any town, in which such poles or structures are to be erected or wires stretched, to locate the route of the lines for such telegraph, telephone, or electric lighting, on, over, and along the public highways in such town or city, and to grant license therefor, upon such conditions as the public good may require.

SEC. 4. The Mayor and aldermen, or the selectmen, shall have the power to grant such license, and may fix and limit the size and location of such poles and structures, their distances from each other, the height from the ground that such wires may be stretched, and the number of wires that may be so used, and the time for which the license shall continue in force, and may revoke the same whenever the public good shall so require, and from time to time, upon like application of such proprietors, or by any person whose rights or interests are affected, may alter and change the location of such poles or structures, and the height and size of the same, as well as the height and number of wires, or may revoke the said license, if proper cause is shown; and all proceedings of the Mayor and aldermen, or selectmen, under this act, shall be sul ject to the supervision of the Supreme Court, on application of any person interested or aggrieved.

SEC. 5. No such poles or structures shall be erected, or wires stretched in any way so as to interfere with any other similar structure.

SEc. 6. If any person shall be aggrieved or damaged by the erection of such poles or structures, or by the stretching of such wires, or by the use made of the same, he may apply to the Mayor and aldermen, or the selectmen, to assess the damages which be claims are occasioned thereby, who shall give notice to such proprietors and all others interested, and after hearing all parties may award such damages as may be legally and justly due. 
SEC. 7. If said Mayor and aldermen, or selectmen, shall neglect or refuse to make such award, or either party shall be dissatisfied therewith, or said proprietors shall neglect or refuse to pay the same within thirty days after such award is made, either party may apply to the Supreme Court for relief, and like proceedings shall be had as in case of appeals from the laying out of highways and the assessment of damages therefor.

SEC. 8. Proceeding;, as provided by this act, may be taken on petition to the Mayor and aldermen, or selectmen, in case any proprietors aforesaid shall desire to lay their wires under the surface of any highway, or in case any person interesied or affected by such poles, structures or wires, or the use made thereof, shall petition therefor.

SEc. 9. Similar proceedings may be had by any such proprietors for locating and licensing any such telegraph, telephone, or electric lighting lines, already constructed, or for changing or altering the location of such lines as may have been heretofore erected.

SEc. zo. Nothing herein contained shall exempt any such proprietors fiom liability for any unlawful entry, trespass, or damage already made or committed, nor from any liability or damage that may occur from want of care or from negligence in erecting or maintaining such poles, structures or wires.

SEC. II. Such proprietors of any telephone or telegraph lines shall open and maintain. at some convenient point or points, offices or places where any person desiring so to do may use such telephone or telegraph line for communication to all points reached by such line or its connections, on payment of a reasonalle fee for such use; and if any such proprietors shall neglect or fail so to open and maintain such offices or places, any person aggrieved may apply to the Supreme Court, by petition, for redress, and the Court shall make such orders and issue such decrees as justice may require.

SEC. 12. Such proprietors of any electric lighting apparatus or lines shall furnish the means of lighting by such electric light to all persons within the reach thereof and applying therefor, upon similar terms and conditions, without discrimination and at reasonatle rates; and any person agyrieved by the neglect or failure to furnish such means, at such rates, may apply to the Supreme Court by peti. tion, for redress, and the Court shall make such orders and decrees as justice may require.

SEc. 13. The use of the highways of this State by telegraph, telephone and electric lighting poles, structures and wires, under and in accordance with the provisions of this act, is hereby declared to be a public use of such highways.

SEC. I4. This act shall take effect upon its passage.

\section{New Hampshire also provides, by " An act for the taxation} of telephone companies" (chap. I IO, Laws, I 883, page 89, act approved I 5 th September, I 883), -

SEC. I. Every telephone corporation, company or person doing business within this State, shall pay an annual tax, as near as may be in proportion to the taxation of other property throughout the State, on the value of any telephone line or lines owned or worked by such corporation, company or person within this State, 
including all poles, wires, insulators, transmitters, telephones, batteries, instriments, telephonic apparatus, office furniture and fixtures.

SEC. 2. The State board of equalization shall appraise the said lines, apparatus, office furniture and machinery at their actual value, and assess such corporation, company or person on said valuation, at the average rate of taxation of other property throughout the State. Such assessment shall be made and certified to the State treasurer by the thirtieth day of September. The State treasurer shall thereupon notify said parties against whom the tax is assessed, and the same shall be paid into the treasury on or before the thirtieth day of October. If any tax so assessed is not paid by the said thirtieth day of October the State treasurer shall issue his extent for the same, and all property of the delinquent corporation, company or person, on the first day of April preceding, shall be liable for its payment.

SEC. 3. This act shall take effect from its passage.

New Jersey has provided for the designation of route, by an act approved 27th April, I 888 (chap. 337, Laws, page 546),-

I. Be it enacted by the Senate and General Assembly of the State of New Jersey, That sections one and two of the act, of which this is amendatory, be and the same are hereby amended to read as follows :

I. Be it, etc., That whenever any telegraph or telephone company, organized by virtue of the act to which this is a further supplement, or by virtue of any special act, shall apply to the Common Council, township committee, or other legislative body of any city, town, township, village or borough in this State (the Common Council, township committee, or other legislative body of which is authorized by law to take and appropriate lands or real estate for the opening, laying out or constructing streets.therein, and to make awards for lands or real estate taken therefor, and to levy assessments for benefits or expenses of such improvements, by a board of assessment or otherwise), through which it is il.tended to construct or extend any telegraph or telephone line, for a designation of the street, streets. or highways, in or upon which the posts or poles of said company may be erected, it shall be the duty of such Common Council, township committee or other legislative body to give to such company a writing, designating the street, streets or highways in which the posts or poles of said company shall be placed, and the manner of placing the same, subject in other respects to the provisions of the act to which this is a supplement; the street, streets or highways to be designated as aforesaid shall be such as form a practicable and suitable continuous route for the line of said company through such municipality, compencing and ending upon a pulilic highway, and shall be designated with due regard to the improvement of facilities for telegraphic or telephonic communications; in case such Common Council, township committee, or other legislative body shall not, within fifty days from the time of the making of such application, give to such company a writing, designating the street, streets or highways in which the posts or poles of such company may be erected, and the manner of placing the same, as hereinbefore provided, it shall be lawful for such company to apply to the Circuit Court of the county in which such city, town, township, village or borough is situate, or to the judge thereof in vacation, and such Court or the judge thereof, after a hearing 
upon twenty days' notice to such Common Council, township committee or other legislative body, which notice shall be published at least once a week, for two weeks, in a newspaper in which the ordinances of such city, town, township, vil. lage or borough are published according to law, or in case there is no such official newspaper, then in a newspaper published in the county, to be designated by said Court or judge, shall, as speedily as possible, hear the matter in question, and may, in the discretion of said Court or judze, designate the street, stieets or highways in which the posts or poles of such company may be erected and the manner of placing the same, which designation shall have the same force and effect as if made by the legislative body of said cily, township, village or borough.

2. And be it enocted, That it shall be unlawful for any telegraph or telephone company to construct or extend any telegraph or telephone line, or to erect any posts or poles therefor, in any city, town, township, village or borough, having the powers enumerated in the first section of this act, without first obtaining such designation of their route, and then only upon the street, streets or highways so to be designated.

2. And be it enacted, That this act shall be deemed a public act and shall take effect immediately.

The Act so amended, was itself an amendatory act, approved I April, I887 (Chap. 87, Laws, page I I9), and also provided-

3. And be it enacted, That the designation of such route provided for in the first section of this act, shall, in all cases, be made by ordinance, where the legislative body of any of the municipal corporations hereinbefore designated, are authorized by law, to enact ordinances for any purpose whatever.

4. And be it enacted, That this act shall be deemed a public act, and shall take effect immediately.

The original act was one "to incorporate and regulate telegraph companies" (Revision of 1877 , page II 74 ), and was further amended by a supplement approved i I March, 1880 (Laws, page 201: Supp. to Revision, I877-1886, page 1022),-

2. And be it enacted, That in case of the refusal of any of the owners of the soil, on the line of the route, to permit the use of any road or highway, for the purpose of erecting posts or poles on the same, to sustain the wires or other fixtures, in case where consent is necessary to be obtained, it shall be lawful for such company to present a petition to the circuit court of the county, in which said road or highways are situate, or to judge thereof in vacation, setting forth the privilege, or right of way, the names of the owners of the soil, if known, and if not known, or non-resident of the State, that fact shall be stated, and the names of any number of owners or any number of descriptions of the premises desired, may be mentioned in one petition; whereupon the said court shall fix the time and place for the hearing of the matter contained in said petition, and direct notice thereof to be served on the person or persons, or corporations interested, at least six days prior to said hearing, sach service to be made in the same manner as writs of summons, issued out of 
said court, are served; or if the owner be unknown, or non-resident in this State, such notice shall be published in a newspaper in ssid county for the like period, or for such longer period as the court may direct; and in case the post office address of such non-resident owner can be ascertained, a copy of such notice sinall be mailed to him or her (postage prepaid), under the direction of said court; at the time mentioned for said hearing the said court (unless good canse to the contrary appear), shall appoint three disinterested freeholders, residents of said cuunty, commissioners to assess and appraise the damages which such owner or owners may sustain, by reason of the erection and establishment of such telegraph line; before entering upon the service, said commissioners shall severally be sworn faithfully and impartially to perform the duties required of them, and shall, on view, make a just appraisal in writing, of the damages, if any, sustained by such owner or owners, and file a report thereof, in the office of the clerk of said court; if any damages are assessed, the company shall pay or tender the amount of the same to the party to whom the award is made; if such owner be unknown, or cannot be found, they shall pay the same into the said court; and thereupon, or if ${ }^{-}$ no damages are found to be sustained, the said company shall have full power to use such road or highway, on the line of their route, for the purpose of erecting posts or poles on the same, to sustain their wires and other fixtures; said commissioners shall each receive three dollars for each day's service performed by them, to be paid by said company; and any party aggrieved by the assessment of damages, may have the matter determined by a jury, provided an appeal be made to the said court within thirty days from the time of fling the report by the said commissioners, and said court shall thereupon order a trial by jury, to be conducted as any other case of similar trial; if the jury increase the damages, the same and all costs and charges shall be paid by the company, otherwise the costs and cliarges to be paid by the owner or party interested; and the judgment may be entered upon the verdict of said jury, and execution issued thereon, as in other cases, unless said company shall, within ten days after said verdict is rendered, elect to abandon their proposed route or appropriation of said road or highway, by an instrument in writing to that effect, to be filed with the clerk of the said court and entered on the minutes thereof; and as to so much as is thus abandoned, the assessment of damages shall be void; provided, that upon such abandonment, the costs of all proceedings to be taxed by the said court, shall be paid by the company to the opposite party; ant provided also, that all the provisions of this section shall apply to any telegraph or telephone company specially incorporated.

3. And be it enacted, That this act shall take effect immediately.

Prescriptive Rights are regulated by an act, approved $2 \mathrm{I}$ April, 1884 (Laws, page 239; Supp. to Revision, 1877-1886, page 1023), -

1. Be it enacted, \&oc., That whenever any wire or cable, used for any telegraph, telephone, electric light, or other wire or cable for electric purposes, is or sliall be attached to, or does or shall extend upon or over any building or land, no lapse of time whatsoever, shall raise a presumption, or justify a prescription of any per-. petual right to such attachment or extension.

(To be continued.)

JoHN B. UhLE. 